\title{
PENGARUH AROMA TERAPI LAVENDER (LAVANDULA ANGUSTIFOLIA) TERHADAP INSOMNIA PADA LANSIA BANJAR TANGTU PUSKESMAS II DENPASAR TIMUR
}

\author{
THE INFLUENCE OF THERAPEUTIC SCENTS OF LAVENDER \\ (LAVANDULA ANGUSTIFOLIA) TO ELDERLY WITH INSOMNIA IN \\ BANJAR TANGTU PUSKESMAS II DENPASAR TIMUR
}

\author{
I Gusti Ayu Diah Sasmitha Dewi1, I Nyoman Asdiwinata2, I Made Arisusana3 \\ Sekolah Tinggi Ilmu Kesehatan Wira Medika Bali1
}

\begin{abstract}
ABSTRAK
Insomnia merupakan salah satu masalah yang sering terjadi pada lansia, di Indonesia insomnia menyerang sekitar 50\% orang yang berusia 65 tahun. Terapi non farmakologi yang dapat digunakan untuk mengatasi insomnia pada lansia antara lain aromaterapi. Aromaterapi yang paling dikenal oleh masyarakat Indonesia adalah aromaterapi lavender karena memiliki efek sedatif yang lebih baik dari pada aroma terapi lainnya. Penelitian ini bertujuan untuk mengetahui pengaruh aroma terapi lavender (lavandula angustifolia) terhadap insomnia pada lansia. Jenis penelitian Quasi Experiment dengan rancangan pre-post test with control group design. Jumlah sampel 22 orang dengan Purposive sampling. Hasil penelitan menunjukkan rata-rata skor tingkat insomnia pada kelompok perlakuan pre test 13,73, pada kelompok kontrol 13.45. Rata-rata skor tingkat insomnia pada kelompok perlakuan post test 6,36 pada kelompok kontrol post test adalah 6,91. Hasil uji statistik Paired $t$ Test kelompok perlakuan didapatkan $\mathrm{p}$ value $=0,000<$ $\alpha 0,05$ pada kelompok kontrol didapatkan nilai $\mathrm{p}$ value $=0,000>\alpha 0,05$. Hasil uji Independen T test didapatkan nilai $\mathrm{p}$ value $=0,443<0,05$ menunjukkan ada perbedaan tingkat insomnia pada lansia pada kelompok perlakuan dan kelompok kontrol. Aroma lavender memiliki efek sedatif sehingga mampu membantu merilekskan tubuh dan dapat membantu memudahkan untuk tidur. Penelitian ini menyarankan agar penggunaan aroma terapi lavender (lavandula angustifolia dapat digunakan untuk menurunkan tingkat insomnia pada lansia serta perlu dikembangkan penelitian lebih lanjut.

Kata Kunci : Aroma Terapi Lavender, Insomnia , Lansia
\end{abstract}

\begin{abstract}
Insomnia is one of the problems that often occur in the elderly, Indonesia around $50 \%$ attack of insomnia than those aged 65 years old. Non pharmacological therapies that can be used to resolve insomnia in the elderly between aromatherapy. Aromatherapy is best known by the people of indonesia that the lavender aromatherapy because it has a sedative effect which is better than on other aroma therapy. This research aims to know the influence of the therapeutic scents of lavender (lavandula angustifolia) against insomnia in the elderly. This type of research is quasi experiment with pre-post test design with control group design. Total sample of 22 peoples by Purposive sampling. The results showed the average value of the Group at the level of insomnia treatment pre test 13.73, 13.45 in the control group. The average score on a group level of insomnia treatment post test control Group post test 6.36 is 6.91. Results the results of the
\end{abstract}


statistical test equipment $t$ test treatment group gain value $p=0000<0.05 \alpha$ value obtained in the control group $p$ value $=0000>0.05$. $\alpha$. the results of the independent T-test test earned value $p=04430.05$ showed no difference in rates of insomnia < parents in the treatment group and the control group. The scent of lavender have sedative effects so that it is able to help relax your body and can help make it easier to sleep. ). The study suggest that therapeutic scents of lavender (lavandula angustifolia) against insomnia in the elderly. And should be developed further research.

Key words : Lavender Aroma Therapy, Insomnia, Elderly

Alamat korespondensi : Stikes Wira Medika PPNI Bali

Email :gungdsd08@gmail.com

\section{LATAR BELAKANG}

Peningkatan jumlah penduduk lansia (lanjut usia) pada dasarnya merupakan dampak positif dari peningkatan derajat kesehatan masyarakat. Peningkatan angka rata-rata tersebut mencerminkan makin bertambah panjangnya masa hidup penduduk secara keseluruhan yang membawa konsekuensi makin bertambahnya jumlah lansia. Jumlah lansia di Indonesia yang semakin bertambah akan membawa pengaruh besar dalam pengelolaan masalah kesehatannya (Koswara, 2010).

Menurut Word Health Organitation (2015) pada tahun 2013-2050, penduduk lansia di dunia akan menduduki peringkat teratas dibandingkan dari golongan usia dibawahnya. Pertambahan penduduk lansia di dunia pada tahun yang sama adalah 13,4\% tahun 2014 dan 25,3\% tahun 2015. Pertambahan penduduk lansia (60 tahun keatas) di Indonesia menunjukkan adanya kecenderungan peningkatan persentase. Tahun 2014 pertambahan penduduk lansia sebanyak 8,9 \% dari total jumlah penduduk pada tahun yang sama. Tahun 2015 pertambahannya sebanyak $21,4 \%$ (Kemenkes, 2015). Urutan penduduk lansia terbanyak di Indonesia adalah Provinsi Daerah Istimewa Yogyakarta 13,04\%, Jawa Timur 10,4\% Jawa Tengah 10,34\% dan Bali 9,78\% (Badan Pusat Statistik RI, 2013). Jumlah penduduk lanjut usia yang berumur 60 keatas di Provinsi Bali sebanyak 565,276 jiwa. Jumlah penduduk lanjut usia tertinggi pertama berada di kabupaten Jembrana dengan 281,917 jiwa, dilanjutkan oleh Kabupaten Tabanan dengan jumlah lansia 64,546 jiwa, Denpasar 50,381 jiwa, Buleleng 42,231 jiwa, Badung 36,452 jiwa, Karangasem 31,252 jiwa, Bangli 30,044 jiwa dan Klungkung 28,453 jiwa (Badan Pusat Statistik Provinsi Bali, 2015). Data dari Dinas Kesehatan Kota Denpasar tahun 2015, jumlah lansia di Kota Denpasar paling banyak ada di Kecamatan Denpasar Timur yaitu sebanyak 14.885 orang dan paling banyak terdapat di wilayah kerja Puskesmas II Denpasar Timur yaitu sebanyak 8872 orang (Dinas Kesehatan Kota Denpasar, 2015).

Salah satu masalah yang sering terjadi pada lansia adalah insomnia atau susah tidur yaitu ketidak mampuan untuk tidur walaupun ada keinginan untuk melakukannya. Insomnia bukan merupakan penyakit, tetapi merupakan gangguan tidur berupa kesulitan tidur. (Asmadi (2008) dalam Kurniawan, (2012). Insomnia pada lansia merupakan keadaan dimana individu mengalami suatu perubahan dalam kuantitas dan kualitas pola istirahatnya yang menyebabkan rasa tidak nyaman atau mengganggu gaya hidup yang diinginkan (Asmadi, 2008). 
Menurut National Sleep Foundation (2010) sekitar 67\% dari 1.508 lansia di Amerika usia 65 tahun ke atas melaporkan mengalami insomnia dan sebanyak 7,3\% lansia mengeluhkan gangguan memulai dan mempertahankan tidur atau insomnia. Kebanyakan lansia beresiko mengalami insomnia yang disebabkan oleh berbagai faktor seperti pensiunan, kematian pasangan atau teman dekat, peningkatan obat-obatan, dan penyakit yang dialami. Di Indonesia insomnia menyerang sekitar 50\% orang yang berusia 65 tahun, setiap tahun diperkirakan sekitar 20\%-50\% lansia melaporkan adanya insomnia dan sekitar 17\% mengalami insomnia yang serius. Prevalensi insomnia pada lansia cukup tinggi yaitu sekitar 67\% (Puspitosari, 2011). Di Provinsi Bali tahun 2015 diperkirakan tiap tahun orang dewasa dan lansia mengalami insomnia sebanyak 112.876 (16,59\%). Kejadian insomnia di Bali tahun 2015 tertinggi di Kota Denpasar mencapai sekitar 18952 orang (16,79\%), dan terrendah di Karangasem mencapai sekitar 9232 orang $(8,17 \%)$ (Dinas Kesehatan Provinsi Bali, 2015).

Insomnia pada lansia disebabkan oleh beberapa faktor, yaitu dari faktor status kesehatan, penggunaan obat-obatan, kondisi lingkungan, stres psikologis, diet/nutrisi, gaya hidup menyumbangkan insomnia pada usia lanjut (Bandiyah, 2012). Insomnia pada lansia juga dihubungkan dengan penurunan memori, konsentrasi terganggu dan perubahan kinerja fungsional. Perubahan yang sangat menonjol yaitu terjadi penurunan gelombang alfa dan meningkatnya frekuensi terbangun di malam hari atau meningkatnya fragmentasi tidur karena seringnya terbangun (Darmojo, (2010) dalam Laraswati, (2014

Dampak insomnia pada lansia; misalnya mengantuk berlebihan di siang hari, gangguan atensi dan memori, mood, depresi, sering terjatuh, penggunaan hipnotik yang tidak semestinya, dan penurunan kualitas hidup. Beberapa gangguan tidur dapat mengancam jiwa baik secara langsung (misalnya insomnia yang bersifat keturunan dan fatal serta apnea tidur obstruktif) atau secara tidak langsung misalnya kecelakaan akibat gangguan tidur. Di Amerika Serikat, lansia yang mengalami kecelakaan akibat gangguan tidur per tahun sekitar delapan puluh juta orang, biaya kecelakaan yang berhubungan dengan gangguan tidur pertahun sekitar seratus juta dolar (World Health Organization, 2015).

Upaya yang dapat dilakukan untuk mengurangi akibat dari insomnia pada lansia diatas diperlukan upaya penanganan yang tepat untuk mengatasinya. Cara yang dapat digunakan untuk mengatasi insomnia antara lain terapi farmakologi dan terapi nonfarmakologi. Terapi farmakologi dapat dilakukan dengan pemberian obat tidur. Obat tidur dapat membantu lansia jika digunakan dengan benar. Tetapi penggunaan jangka panjang dapat mengganggu tidur dan menyebabkan masalah yang lebih serius seperti ketergantungan akan obat, penurunan metabolisme pada lansia, penurunan fungsi ginjal, dan menyebabkan kerusakan fungsi kognitif (Stanley, 2007 dalam Aziz, 2016).

Terapi non farmakologi yang dapat digunakan untuk mengatasi insomnia pada lansia antara lain terapi rekreasi, terapi musik, pijat aromaterapi, yoga, relaksasi progresif, meditasi dan aromaterapi (Rahmawati, 2015). Aromaterapi merupakan tehnik relaksasi menggunakan konsentrasi minyak esensial dari tumbuhan, sekalipun metode yang digunakan tergolong sederhana, namun terapi ini memiliki banyak kelebihan dibandingkan dengan metode penyembuhan yang lain seperti biaya yang dikeluarkan relatif murah, bisa dilakukan diberbagai tempat dan keadaan, cara pemakaian tergolong praktis dan efisien, efek zat yang ditimbulkan 
tergolong cukup aman bagi tubuh dan khasiatnya pun terbukti cukup manjur dan tidak kalah dengan metode terapi lain (Jaelani, 2012). Berbagai macam cara digunakan dalam melakukan tehnik dengan aromaterapi salah satunya adalah dengan cara inhalasi yaitu menghirup minyak aromaterapi dan ini merupakan cara penyembuhan yang paling cepat (Hadibroto \& Alam, 2012).

Aromaterapi terdiri dari beberapa jenis diantaranya jasmine, kenanga, lemon, mawar, pepermint, Camomile, Clary sage, Cypress, Eucalyptus, Grapefruit, Lavender, Tea Tree dan lain-lain. Aromaterapi yang paling dikenal oleh masyarakat indonesia adalah aromaterapi lavender karena memiliki efek sedatif yang lebih baik dari pada aroma terapi lainnya (Nuraini, 2014). Penggunaan aromaterapi secara umum sangat aman, namun bisa menimbulkan efek samping berupa pusing dan mual apabila menghirup aromaterapi tersebut terlalu lama yaitu lebih dari 1 tahun dan terlalu sering yaitu lebih dari 10 kali perhari (Bararah, 2015)

Aromaterapi lavender (Lavandula angustifolia) merupakan salah satu tanaman alternatif sebagai penyembuhan, bunga dari tanaman ini menghasilkan produk parfum kelas tinggi yang banyak dipakai oleh para bangsawan Eropa (Jaelani, 2012). Aromaterapi lavender (Lavandula angustifolia) bekerja dengan merangsang sel saraf penciuman dan mempengaruhi sistem kerja limbik dengan meningkatkan perasaan positif dan rileks. Aromaterapi yang digunakan dalam penelitian ini adalah jenis dimana produknya menggunakan lilin aromaterapi lavender agar mudah digunakan. Kandungan dari lilin aromaterapi lavender adalah Menthol 10\%, Camphor 5\%, Olive Virgin Oil 10\%, Essensial Oil linalool 45\%), dan linalool asetat (30\%) (Nuraini, 2014).

Aroma lavender (Lavandula angustifolia) memiliki efek sedatif sehingga mampu membantu merilekskan tubuh dan dapat membantu memudahkan kita untuk tidur setelah menghirupnya beberapa saat. Aroma terapi lavender (Lavandula angustifolia) didasari teori bahwa wangi lavender akan memenuhi hipotalamus, bagian otak yang mengendalikan sistem kelenjar dan hormon sehingga memenuhi mood dan menurunkan tingkat stres. Saat aroma ini dihirup, molekul-molekulnya masuk melalui hidung menuju ke reseptor olfaktoris. Reseptor ini kemudian mengirimkan informasi mengenai bau yang tercium pada sistem limbik di dalam otak. Sistem limbik di dalam otak tidak hanya memproses penerima bau, namun juga mengatur emosi, sehingga dapat dipahami mengapa bau- bauan tertentu dapat mempengaruhi perasaan kita. Selain itu, sistem limbik juga berpengaruh terhadap produksi hormon (Wijayanti, 2014).

Beberapa penelitian telah membuktikan aromaterapi memberikan dampak yang signifikan terhadap insomnia yang dialami lansia diantaranya oleh Rahmawati (2015) tentang efektifitas mandi air hangat dan aroma terapi lavender terhadap insomnia pada lansia. Hasil penelitian disimpulkan kelompok aromaterapi lavender lebih efektif untuk menurunkan insomnia dari pada kelompok mandi air hangat $(0,017)<\alpha \quad 0,05)$. Penelitian Azis (2016) tentang pengaruh pemberian terapi masase kaki dan aroma terapi sereh terhadap penurunan insomnia pada lansia di Panti Wredha Daerah Surakarta. Hasil penelitian disimpulkan ada pengaruh aromaterapi sereh terhadap penurunan insomnia pada lansia $(0,000)<\alpha 0,05)$.

Berdasarkan studi pendahuluan yang peneliti lakukan pada bulan Januari 2017 di Puskesmas II Denpasar Timur, gangguan yang paling banyak dikeluhkan oleh lansia dan sudah terdiagnosa pada tahun 2016 adalah insomnia sebanyak 65 orang, 
kecemasan sebanyak 31 orang dan dimensia sebanyak 23 orang. Menurut data, dari 6 desa yang berada wilayah kerja di Puskesmas II Denpasar Timur, bahwa kunjungan lansia dengan insomnia yang paling banyak berasal dari Banjar Tangtu sebanyak 38 orang.

Berdasarkan survei awal yang dilakukan peneliti pada bulan Januari 2017 di Banjar Tangtu dengan melakukan wawancara terhadap 5 orang lansia yang sudah terdiagnosa mengalami insomnia. Lansia yang terindikasi mengalami insomnia semuanya mengatakan bahwa susah memulai tidur dan sering terbangun pada malam hari. Upaya yang dilakukan oleh lansia untuk mengatasi gangguan tidur yang selama ini dilakukan adalah minum obat yang diberikan di Puskesmas. Upaya lain yang dilakukan lansia adalah dengan membaca, menonton televisi, mejejahitan, mendengarkan musik tradisional Bali dan olah raga jalan kaki. Upaya yang dilakukan tersebut terkadang dapat membantu mengatasi gangguan tidur tetapi juga sering tidak berhasil membantu mengatasi gangguan tidur lansia. Berdasarkan hasil wawancara terhadap petugas pemegang program lansia mengatakan belum pernah adanya pemberian aroma terapi lavender (Lavandula angustifolia) pada lansia. Berdasarkan uraian diatas penulis sangat tertarik untuk mengetahui lebih mendalam tentang "Pengaruh aroma terapi lavender (lavandula angustifolia) terhadap tingkat insomnia pada lansia Banjar Tangtu Puskesmas II Denpasar Timur”.

\section{METODE}

Jenis penelitian ini adalah Quasi Experiment yang bertujuan untuk mengungkapkan hubungan sebab akibat dengan cara melibatkan kelompok kontrol disamping kelompok eksperimen (Nursalam, 2013). Rancangan yang digunakan dalam penelitian ini adalah pre-post test with control group design.

Pengambilan data dilakukan di Banjar Tangtu Puskesmas II Denpasar Timur pada tanggal 21 Juni sampai 8 Juli tahun 2017.. Sampel dalam penelitian ini ditentukan berdasarkan kriteria inklusi. Jumlah sampel sebanyak 22 orang sampel, dengan 11 orang sampel sebagai kelompok perlakuan dan 11 orang sebagai kelompok kontrol, tehnik sampling yang digunakan adalah Purposive sampling" Variabel independen dalam penelitian ini aroma terapi lavender (lavandula angustifolia). Variabel dependen dalam penelitian ini adalah tingkat insomnia pada lansia

Prosedur analisis dalam penelitian ini proses pengolahan data mengikuti langkah - langkah sebagai berikut editing, coding, entri data dan cleaning atau tabulasi. Analisa data pada penelitian ini mengunakan uji“Paired $t$ test dan independent $t$ test'. Penentuan hipotesis diterima atau ditolak apabila nilai probability lebih kecil dari nilai signifikansi $(\mathrm{p}<0,05)$ maka ada pengaruh aroma terapi lavender (lavandula angustifolia) terhadap tingkat insomnia pada lansia Banjar Tangtu Puskesmas II Denpasar Timur.

\section{HASIL PENELITIAN}

1. Umur

\begin{tabular}{lllllll}
\hline $\mathrm{N}$ & \multirow{2}{*}{ Umur } & \multicolumn{2}{c}{ Perlakuan } & \multicolumn{2}{c}{ Kontrol } \\
\cline { 3 - 6 } $\mathrm{o}$ & & $\mathrm{f}$ & $\%$ & $\mathrm{f}$ & $\%$ \\
\hline- & $\underline{60-74}$ & $\underline{5}$ & $\underline{45.5}$ & $\underline{5}$ & $\underline{45.5}$ \\
\hline & $\underline{75-90}$ & $\underline{6}$ & $\underline{54.5}$ & & $\underline{6}$ & $\underline{54.5}$
\end{tabular}


Total $\quad \underline{11} \quad \underline{100,0} \quad \underline{11} \quad \underline{100,0}$

Berdasarkan tabel diatas didapatkan hasil karakteristik responden berdasarkan umur pada kelompok perlakuan dan kontrol sebagian besar yaitu masing-masing 6 orang $(54,5 \%)$ pada kelompok perlakuan dan kelompok kontrol berumur 75-90 tahun.

2. Jenis kelamin

\begin{tabular}{|c|c|c|c|c|c|}
\hline \multirow{2}{*}{$\begin{array}{l}\mathrm{N} \\
\mathrm{O}\end{array}$} & \multirow{2}{*}{$\begin{array}{l}\text { Jenis } \\
\text { Kelamin }\end{array}$} & \multicolumn{2}{|c|}{ Perlakuan } & \multicolumn{2}{|c|}{ Kontrol } \\
\hline & & $\mathrm{f}$ & $\%$ & $\mathrm{f}$ & $\%$ \\
\hline \multirow{3}{*}{ - } & Laki-laki & 2 & 18.2 & 3 & 27.3 \\
\hline & Perempuan & 9 & $\underline{81.8}$ & $\underline{8}$ & $\underline{72.7}$ \\
\hline & Total & $\underline{11}$ & $\underline{100,0}$ & 11 & $\underline{100,0}$ \\
\hline
\end{tabular}

Berdasarkan tabel diatas didapatkan hasil karakteristik responden berdasarkan jenis kelamin sebagian besaryaitu sebanyak 9 orang $(81,8 \%)$ pada kelompok perlakuan

dan sebanyak 8 orang $(72,7 \%)$ pada kelompok kontrol berjenis kelamin perempuan.

3. Pendidikan

\begin{tabular}{|c|c|c|c|c|c|}
\hline \multirow{2}{*}{$\begin{array}{l}\mathrm{N} \\
\mathrm{O}\end{array}$} & \multirow{2}{*}{$\begin{array}{l}\text { Pendidika } \\
\mathrm{n}\end{array}$} & \multicolumn{2}{|c|}{ Perlakuan } & \multicolumn{2}{|c|}{ Kontrol } \\
\hline & & $\mathrm{f}$ & $\%$ & $\mathrm{f}$ & $\%$ \\
\hline - & $\underline{\mathrm{SD}}$ & $\underline{8}$ & $\underline{72.7}$ & $\underline{6}$ & 54.5 \\
\hline- & SMP & $\underline{1}$ & 9.1 & $\underline{3}$ & 27.3 \\
\hline- & $\underline{\mathrm{SMA}}$ & $\underline{2}$ & $\underline{18.2}$ & $\underline{2}$ & $\underline{18.2}$ \\
\hline & Total & $\underline{11}$ & 100,0 & $\underline{11}$ & 100,0 \\
\hline
\end{tabular}

Berdasarkan tabel diatas didapatkan hasil karakteristik responden berdasarkan pendidikan sebagian besar yaitu sebanyak 8 orang $(72,7 \%)$ pada kelompok perlakuan dan sebanyak 6 orang $(54,5 \%)$ pada kelompok kontrol tamat SD.

4. Pekerjaan

\begin{tabular}{|c|c|c|c|c|c|}
\hline \multirow[t]{2}{*}{$\mathrm{N}$} & \multirow[t]{2}{*}{ Pekerjaan } & \multicolumn{2}{|c|}{ Perlakuan } & \multicolumn{2}{|c|}{ Kontrol } \\
\hline & & $\mathrm{f}$ & $\%$ & $\mathrm{f}$ & $\%$ \\
\hline & Tidak & $\underline{10}$ & 90.9 & 9 & $\underline{81.8}$ \\
\hline & Wiraswasta & $\underline{1}$ & 9.1 & $\underline{2}$ & $\underline{18.2}$ \\
\hline & Total & 11 & $\begin{array}{c}100 \\
0\end{array}$ & 11 & 100,0 \\
\hline
\end{tabular}


Berdasarkan tabel diatas didapatkan hasil karakteristik responden berdasarkan pekerjaan, sebagian besaryaitu sebanyak 10 orang $(90,9 \%)$ pada kelompok perlakuan dan sebanyak 9 orang $(81,8 \%)$ pada kelompok kontrol tidak bekerja.

Hasil pengamatan terhadap obyek penelitian berdasarkan variabel penelitian

1. Tingkat insomnia pada lansia sebelum diberikan aroma terapi lavender (lavandula angustifolia) pada kelompok perlakuan dan kelompok kontrol

\begin{tabular}{|c|c|c|c|c|c|}
\hline $\begin{array}{l}\text { Tingkat } \\
\text { Insomnia }\end{array}$ & Mean & Median & $\begin{array}{l}\text { Min- } \\
\text { Max }\end{array}$ & SD & $\begin{array}{c}95 \% \text { CI } \\
\text { Lower- } \\
\text { Upper }\end{array}$ \\
\hline Perlakuan & 13.73 & 13.00 & $11-18$ & 2.370 & $\begin{array}{l}12.13- \\
15.32 \\
\end{array}$ \\
\hline Kontrol & 13.45 & 12.00 & $8-20$ & 3.698 & $\begin{array}{c}10.97- \\
15.94 \\
\end{array}$ \\
\hline
\end{tabular}

Berdasarkan tabel diatas menunjukkan rata-rata skor tingkat insomnia lansia pada kelompok perlakuan sebelum diberikan aroma terapi lavender adalah 13,73 termasuk kategori tinggi dengan nilai minimum 11 dan maximum 18. Hasil estimasi interval dapat disimpulkan bahwa 95\% diyakini bahwa rata-rata skor tingkat insomnia pre test adalah diantara 12.13 sampai dengan 15.32. Rata-rata skor tingkat insomnia lansia pada kelompok kontrol pre test adalah 13.45 termasuk kategori tinggi dengan nilai minimum 8 dan maximum 20. Hasil estimasi interval dapat disimpulkan bahwa 95\% diyakini bahwa rata-rata skor tingkat dimensia pre test adalah diantara 10.97 sampai dengan 15.94 .

2 Tingkat insomnia pada lansia setelah diberikan aroma terapi lavender (lavandula angustifolia) dengan spray pada kelompok perlakuan dan kelompok kontrol yang diberikan aroma terapi lavender (lavandula angustifolia) dengan lilin

\begin{tabular}{lcrrrr}
\hline $\begin{array}{l}\text { Tingkat } \\
\text { Insomnia }\end{array}$ & Mean & $\begin{array}{r}\text { Median Min- } \\
\text { SD }\end{array}$ & $\begin{array}{l}\text { 95\% CI } \\
\text { Lower- } \\
\text { Upper }\end{array}$ \\
$\begin{array}{l}\text { Perlaku } \\
\text { an }\end{array}$ & 6.36 & 6.00 & $\underline{4-9}$ & 1.502 & $5.35-7.37$ \\
$\underline{\underline{\text { Kontrol }}}$ & $\underline{6.91}$ & $\underline{7.00}$ & $\underline{4-10}$ & $\underline{1.758}$ & $\underline{5.73-8.09}$ \\
\hline
\end{tabular}

Berdasarkan tabel diatas menunjukkan rata-rata skor tingkat insomnia lansia pada kelompok perlakuan setelah diberikan aroma terapi lavender adalah 6,36 termasuk kategori rendah dengan nilai minimum 4 dan maximum 9. Hasil estimasi interval dapat disimpulkan bahwa 95\% diyakini bahwa rata-rata skor tingkat insomnia pre test adalah diantara 5,35 sampai dengan 7,37. Rata-rata skor tingkat insomnia lansia pada kelompok kontrol 
post test adalah 6,91 termasuk kategori rendah dengan nilai minimum 4 dan maksimum 10.

\section{HASIL ANALISIS DATA}

1. Hasil analisis pengaruh pemberian aroma terapi Lavender (Lavandula angustifolia) dengan spray terhadap tingkat insomnia pada kelompok perlakuan dan pengaruh pemberian aroma terapi Lavender (Lavandula angustifolia) dengan lilin terhadap tingkat insomnia pada kelompok control Control

\begin{tabular}{|c|c|c|c|c|c|}
\hline Sampel & $\begin{array}{l}\text { Tingkat } \\
\text { Insomnia }\end{array}$ & Mean & $\begin{array}{l}\text { Selisih } \\
\text { mean }\end{array}$ & $\begin{array}{c}\mathrm{p} \\
\text { value }\end{array}$ & t hitung \\
\hline $\begin{array}{l}\text { Kelompok } \\
\text { perlakuan }\end{array}$ & $\frac{\text { Pre Test }}{\text { Post Test }}$ & $\frac{13.73}{6.36}$ & 7.364 & 0.000 & 13.140 \\
\hline $\begin{array}{l}\text { Kelompok } \\
\text { kontrol }\end{array}$ & $\begin{array}{c}\text { Pre Test } \\
\text { Post } \\
\text { Test } \\
\end{array}$ & $\frac{13.45}{6.91}$ & 6.545 & 0.000 & 8.050 \\
\hline
\end{tabular}

Berdasarkan tabel di atas dapat diketahui hasil uji statistik Paired t Test kelompok perlakuan didapatkan nilai $\mathrm{t}_{\text {hitung }}=13,140>\mathrm{t}$ tabel $\mathrm{df} 10=2.228$ dan $\mathrm{p}$ value $=0,000<\alpha 0,05$ menunjukkan ada pengaruh pemberian aroma terapi Lavender (Lavandula angustifolia) dengan spray terhadap tingkat insomnia pada kelompok perlakuan. Selain itu dapat dilihat adanya penurunan skor sebelum dan sesudah pemberian aroma terapi lavender sebesar 7.364. Hasil uji statistik Paired $t$ Test kelompok kontrol didapatkan nilai $\mathrm{t}$ hitung $=8,050>\mathrm{t}$ tabel $\mathrm{df} 10=2.228$ dan $\mathrm{p}$ value $=0,000<\alpha 0,05$ menunjukkan ada pengaruh pemberian aroma terapi Lavender (Lavandula angustifolia) dengan lilin terhadap tingkat insomnia pada kelompok kontrol. Selain itu dapat dilihat adanya penurunan skor pre test dan post test sebesar 6,545.

2. Hasil analisis perbedaan tingkat insomnia pada lansia pada kelompok perlakuan yang diberikan aroma terapi lavender (lavandula angustifolia) dengan spray dan kelompok kontrol yang diberikan aroma terapi lavender (lavandula angustifolia) dengan lilin.

\begin{tabular}{|l|l|l|l|l|l|}
\hline No & $\begin{array}{l}\text { Kelompok } \\
\text { Sampel }\end{array}$ & N & Mean & $\begin{array}{l}\text { Nilai } \\
\text { Beda } \\
\text { rata-rata }\end{array}$ & P Value \\
\hline 1 & $\begin{array}{l}\text { Kelompok } \\
\text { Perlakuan }\end{array}$ & 11 & 6.36 & & 0.545 \\
\hline 2 & $\begin{array}{l}\text { Kelompok } \\
\text { Kontrol }\end{array}$ & 11 & 6.36 & 0.443 \\
\hline
\end{tabular}

Berdasarkan hasil uji Independen $T$ test didapatkan beda rata-rata skor tingkat insomnia kelompok perlakuan dan kelompok kontrol sebesar 0,545 dan nilai $\mathrm{p}$ value $=0,443<0,05$ menunjukkan ada perbedaan tingkat insomnia pada lansia pada kelompok perlakuan yang diberikan aroma 
terapi lavender (lavandula angustifolia) dengan spray dan kelompok kontrol yang diberikan aroma terapi lavender (lavandula angustifolia) dengan lilin.

\section{PEMBAHASAN}

1. Tingkat insomnia pada lansia sebelum diberikan aroma terapi lavender (Lavandula angustifolia) pada kelompok perlakuan dan kelompok kontrol Hasil penelitian menunjukkan rata-rata skor tingkat insomnia lansia pada kelompok perlakuan sebelum diberikan aroma terapi lavender adalah 13,73 termasuk kategori tinggi dengan nilai minimum 11 dan maximum 18. Rata-rata skor tingkat insomnia lansia pada kelompok kontrol pre test adalah 13.45 termasuk kategori tinggi dengan nilai minimum 8 dan maximum 20. Hasil penelitian yang menunjukkan sebagian besar responden mengalami insomnia kategori tinggi menurut Potter \& Perry (2010) lansia banyak mengalami perubahan salah satunya adalah perubahan neurologis. Akibat penurunan jumlah neuron fungsi neurotransmitter juga berkurang. Lansia sering mengeluh meliputi kesulitan untuk tidur, kesulitan untuk tetap terjaga, kesulitan untuk tidur kembali tidur setelah terbangun di malam hari, terjaga terlalu cepat, dan tidur siang yang berlebihan. Masalah ini diakibatkan oleh perubahan terkait usia dalam siklus tidur-terjaga.

Menurut Lumbantobing (2010) Insomnia pada lansia disebabkan oleh beberapa faktor, yaitu dari faktor status kesehatan, penggunaan obat-obatan, kondisi lingkungan,stres psikologis, diet/nutrisi, gaya hidup menyumbangkan insomnia pada usia lanjut. Insomnia pada usia lanjut dihubungkan dengan penurunan memori, konsentrasi terganggu dan perubahan kinerja fungsional. Perubahan yang sangat menonjol yaitu terjadi pengurangan pada gelombang lambat, terutama stadium 4, gelombang alfa menurun, dan meningkatnya frekuensi terbangun di malam hari atau meningkatnya fragmentasi tidur karena seringnya terbangun.

Hasil penelitian ini didukung oleh hasil penelitian Rahmawati (2015) tentang efektifitas mandi air hangat dan aroma terapi lavender terhadap insomnia pada lansia di PSTW Tresna Wredha Abiyoso Yogyakarta. Hasil penelitian menunjukkan bahwa skor insomnia pada kelompok mandi air hangat sebelum diberi perlakuan mandi air hangat skornya adalah 23 dan paling rendah 18 dengan rerarta 20,34, sedangkan pada kelompok lavender sebelum diberikan aromaterapi skor insomnia paling tinggi 23 dan paling rendah 17 dengan rerata 19,32. Hasil penelitian Aziz. (2016) tentang pengaruh aromaterapi sereh terhadap penurunan insomnia pada lansia Di Panti Wredha Daerah Surakarta. Hasil penelitian menunjukkan bahwa skor insomnia sebelum diberi perlakuan aromaterapi sereh skornya adalah 23 dan paling rendah 19 dengan rerarta 19,20.

Menurut pendapat peneliti pada umumnya lansia mengalami penurunan fungsi kognitif dan psikomotor. Faktor yang mempengaruhi perubahan mental yaitu: perubahan fisik, kesehatah umum, tingkat pendidikan, keturunan, lingkungan. Dari segi mental emosional lansia sering muncul perasaan pesimis, timbulnya perasaan tidak aman dan cemas, adanya kekacauan mental akut, merasa terancam akan timbulnya suatu penyakit atau takut di terlantarkan karena tidak berguna lagi. Dengan adanya hal tersebut maka lansia akan menjadi lebih banyak mementingkan kehidupan akhirat daripada kehidupan 
duniawi, selain itu lansia biasanya sering mengingat atau merenungi setiap perbuatan yang dilakukannya selama masa mudanya sebagai bekal ansia kelak di akhirat. Dengan adanya hal tersebut maka lansia menjadi susah untuk memulai tidurnya.

2 Tingkat insomnia pada lansia setelah diberikan aroma terapi lavender (lavandula angustifolia) dengan spray pada kelompok perlakuan dan kelompok kontrol yang diberikan aroma terapi lavender (lavandula angustifolia) dengan lilin

Hasil penelitian menunjukkan rata-rata skor tingkat insomnia lansia pada kelompok perlakuan setelah diberikan aroma terapi lavender adalah 6,36 termasuk kategori rendah dengan nilai minimum 4 dan maximum 9. Rata-rata skor tingkat insomnia lansia pada kelompok kontrol post test adalah 6,91 termasuk kategori rendah dengan nilai minimum 4 dan maximum 10.

Hasil penelitian ini sesuai dengan teori Nuraini. (2014) aroma wangi yang ditimbulkan dari lavender dipercaya mempunyai efek yang sensitive terhadap sistem limbik di otak, dimana bagian tersebut berhubungan dengan emosional dan memori pada manusia. Molekul yang dilepaskan ke udara adalah sebagai uap air. Ketika uap air yang mengandung komponen kimia tersebut dihirup, akan diserap tubuh melalui hidung dan paru-paru yang kemudian masuk ke aliran darah. Uap aromaterapi dihirup, molekul uap tersebut akan berjalan mempengaruhi sistem limbik otak yang bertanggung jawab dalam sistem integrasi dan ekspresi perasaan, belajar, ingatan, emosi, rangsangan fisik, serta memberikan perasaan rilek sehingga memberikan lingkungan tidur yang nyaman.

Menurut Muchtaridi (2013) mekanisme aromaterapi lavender masuk ke dalam tubuh manusia dan bereaksi secara fisiologis. Aroma yang dihirup melalui lapisan rambut halus yang terdapat di hidung akan dikirimkan ke bagian otak yang disebut sistem limbik. Sistem limbik ini berguna untuk mengendalikan perasaan, emosi, dan memori yang juga melepaskan endorfin dan neurotrans-mitter di dalam tubuh. Ketika otak bereaksi terhadap kekuatan positif dari aroma, dapat memperbaiki kondisi emosional yang menyenangkan dan dapat menyebabkan relaksasi. Bunga lavender mengandung linalyl asetat dan linalool yang menimbulkan efek anti cemas (relaksasi) pada lavender.

Hasil penelitian ini didukung oleh hasil penelitian Rahmawati (2015) tentang efektifitas mandi air hangat dan aroma terapi lavender terhadap insomnia pada lansia di PSTW Tresna Wredha Abiyoso Yogyakarta. Hasil penelitian menunjukkan bahwa skor insomnia pada kelompok mandi air hangat setelah diberi perlakuan mandi air hangat skornya adalah 22 dan paling rendah 11 dengan nrerarta 15,82 sedangkan pada kelompok lavender setelah diberikan aromaterapi skor insomnia paling tinggi 21 dan paling rendah 10 dengan rerata 13,32. Hasil penelitian Aziz. (2016) tentang pengaruh aromaterapi sereh terhadap penurunan insomnia pada lansia Di Panti Wredha Daerah Surakarta. Hasil penelitian menunjukkan bahwa skor insomnia sebelum diberi perlakuan aromaterapi sereh skornya adalah 230dan paling rendah 10 dengan rerarta 14,03.

Menurut peneliti lavender aromatherapy dapat menurunkan insomnia pada lansia setelah diberikan aroma terapi lavender (lavandula angustifolia) dengan spray pada kelompok perlakuan dan kelompok kontrol yang diberikan aroma 
terapi lavender (lavandula angustifolia) dengan lilin, karena aroma terapi lavender (lavandula angustifolia) dengan spray dan lilin memiliki kandungan mampu mengubah emosi dan merilekskan tubuh. Aroma yang dihirup akan diteruskan ke sistem limbik. Sistem limbik berfungsi mengendalikan perasaan, emosi, dan memori juga melepaskan endorfin dan neurotransmitter ke dalam tubuh. Ketika otak bereaksi terhadap kekuatan positif dari aroma, dapat memperbaiki kondisi emosional yang menyenangkan dan menyebabkan relaksasi.

\section{Pengaruh pemberian aroma terapi lavender (Lavandula angustifolia)} dengan spray terhadap tingkat insomnia pada kelompok perlakuan dan pengaruh pemberian aroma terapi lavender (lavandula angustifolia) dengan lilin terhadap tingkat insomnia pada kelompok kontrol Berdasarkan hasil uji statistik Paired $t$

Test kelompok perlakuan didapatkan nilai t hitung $=13,140>\mathrm{t}$ tabel $\mathrm{df} 10=$ 2.228 dan $p$ value $=0,000<\alpha 0,05$ menunjukkan ada pengaruh pemberian aroma terapi Lavender (Lavandula angustifolia) dengan spray terhadap tingkat insomnia pada kelompok perlakuan. Selain itu dapat dilihat adanya penurunan skor sebelum dan sesudah pemberian aroma terapi lavender sebesar

7.364. Hasil uji statistik Paired $t$ Test kelompok kontrol didapatkan nilai t hitung $=8,050<\mathrm{t}_{\text {tabel }} \mathrm{df} 10=2.228$ dan $\mathrm{p}$ value $=0,000>\alpha 0,05$ menunjukkan ada pengaruh pemberian aroma terapi Lavender (Lavandula angustifolia) dengan lilin terhadap tingkat insomnia pada kelompok kontrol. Selain itu dapat dilihat adanya penurunan skor pre test dan post test sebesar 6,545.

Hasil penelitian ini sesuai dengan teori Sharma (20110) yang mengatakan aromaterapi lavender (Lavandula Angustifolia) memiliki khasiat menenangkan, sedatif dan membantu meregulasi sistem saraf pusat. Mekanisme aromaterapi ini dimulai dari aromaterapi bunga lavender yang dihirup memasuki hidung dan berhubungan dengan silia, bulu-bulu halus di dalam lapisan dalam hidung. Penerima- penerima di dalam silia dihubungkan dengan alat penghirup yang berada di ujung saluran bau. Ujung saluran ini selanjutnya dihubungkan dengan otak itu sendiri. Baubauan diubah oleh silia menjadi impuls listrik yang dipancarkan ke otak melaui sistem penghirup. Semua impulsi mencapai sistem limbik di hipotalamus. Selanjutnya akan meningkatkan gelombang-gelombang alfa di dalam otak dan justru gelombang inilah yang membantu kita untuk merasa rileks.

Menurut Buckle, (2011) lavender memiliki kandungan lebih dari 160 konstituen, banyak yang berinteraksi secara sinergis untuk berkontribusi terhadap efek penyembuhannya. Konstituen aktif utama minyak lavender adalah linalool. Linalool juga menghambat pelepasan asetilkolin dan mempengaruhi konduktansi ion dalam neuron dan linalool digambarkan untuk mengerahkan efek relaksasi molekul-molekul zat ini akan menyatu dengan udara. Saat dihirup molekul-molekul masuk melalui hidung menuju ke reseptor olfaktoris, reseptor ini kemudian mengirimkan informasi mengenai bau yang tercium kepada sistem limbik di dalam otak. Sistem limbik di dalam otak tidak hanya memproses penerimaan bau namun juga 
mengatur emosi, sehingga dipahami mengapa bau-bauan dapat mempengaruhi perasaan kita. Selain itu sistem limbik berpengaruh terhadap produksi hormon serotonin yang membuat perubahan fisiologis pada tubuh, pikiran, jiwa dan menghasilkan efek menenangkan pada tubuh.

Hal ini diperkuat oleh penelitian yang dilakukan oleh Hardy dan Kikuchi (2010) dalam (Muchtaridi, 2013) hasil uji statistik Paired t Test didapatkan nilai $\mathrm{p}$ value $=0,000$ menunjukkan ada pengaruh pemberian aroma terapi lavender terhadap tingkat insomnia, terjadi penurunan skor insomnia sebesar 4,2, dijelaskan bahwa pemberian aromaterapi lavender selama 2 minggu dilakukan 2 kali sehari sangat efektif dalam menggantikan obat-obatan hipnotik sedatif sintesis dikarenakan pada aromaterapi lavender ini terdapat kandungan berupa linalool dan linalool asetat dimana linalool merupakan kandungan aktif utama untuk rileksasi dan memiliki efek untuk menekan stress atau berefek sedatif. Penelitian Rahmawati (2015) tentang efektifitas mandi air hangat dan aroma terapi lavender terhadap insomnia pada lansia. Pemberian aromaterapi lavender selama 2 minggu dilakukan 2 kali sehari sangat efektif dalam menurunkan tingkat insomnia pada lansia $(0,000)<\alpha$ $0,05)$ dan terjadi penurunan skor insomnia sebesar 3,5 dari 19,32 menjadi 15,82 .

Menurut peneliti, pemberian aroma terapi lavender (lavandula angustifolia) dengan spray dan lilin berpengaruh terhadap tingkat insomnia, hal ini disebabkan karena baik dengan spray dan lilin menghasilkan wangi yang harum dimana keharumannya tidak hanya memberikan rasa tenang dan membangkitkan mood saja melainkan juga memberikan manfaat berupa membantu menyeimbangkan kinerja hormon dalam tubuh, mengatasi gangguan tidur. Selain itu aroma terapi lavender dengan spray dan lilin memiliki kandungan yang sama yaitu linalyl asetat dan linalool yang dapat menimbulkan efek relaksasi, membantu meningkatkan gairah dan semangat hidup sekaligus dapat menimbulkan perasaan tenang sehingga dapat mengurangi kecemasan dan perasaan gelisah sehingga hal tersebut dapat meningkatkan kwalitas tidur lansia.

4. Perbedaan tingkat insomnia pada lansia pada kelompok perlakuan yang diberikan aroma terapi lavender (lavandula angustifolia) dengan spray dan kelompok kontrol yang diberikan aroma terapi lavender (lavandula angustifolia) dengan lilin

Hasil penelitian berdasarkan uji Independen T test didapatkan beda rata-rata skor tingkat insomnia kelompok perlakuan dan kelompok kontrol sebesar 0,545 dan nilai $\mathrm{p}$ value $=0,443<0,05$ menunjukkan ada perbedaan tingkat insomnia pada lansia pada kelompok perlakuan yang diberikan aroma terapi lavender (lavandula angustifolia) dengan spray dan kelompok kontrol yang diberikan aroma terapi lavender (lavandula angustifolia) dengan lilin.

Hasil penelitian yang menunjukkan tidak ada perbedaan tingkat insomnia antara kelompok perlakuan yang diberikan aroma terapi lavender (lavandula angustifolia) dengan spray dan kelompok kontrol yang diberikan aroma terapi lavender (lavandula angustifolia) dengan lilin, karena penggunaan aroma terapi lavender (lavandula angustifolia) dengan spray dan lilin merupakan metode nonfarmakologi dan komplementer untuk penanganan insomnia. Hal ini sesuai 
dengan teori Hadibroto \& Alam, (2012) menghirup minyak aromaterapi dan ini merupakan cara penyembuhan yang paling cepat, lavender adalah salah satu aromaterapi yang terkenal memiliki efek menenangkan, sehingga dapat digunakan sebagai manajemen stres. Menurut beberapa penelitian, minyak lavender lavender 14 sendiri berpengaruh secara signifikan terhadap penurunan tingkat kecemasan, peningkatan relaksasi, dan peningkatan rasa kantuk, serta adanya perbaikan mood.

Menurut (Wijayanti, 2014) aroma lavender (Lavandula angustifolia) memiliki efek sedatif sehingga mampu membantu merilekskan tubuh dan dapat membantu memudahkan kita untuk tidur setelah menghirupnya beberapa saat. Aroma terapi lavender (Lavandula angustifolia) didasari teori bahwa wangi lavender akan memenuhi hipotalamus, bagian otak yang mengendalikan sistem kelenjar dan hormon sehingga memenuhi mood dan menurunkan tingkat stres. Saat aroma ini dihirup, molekul- molekulnya masuk melalui hidung menuju ke reseptor olfaktoris. Reseptor ini kemudian mengirimkan informasi mengenai bau yang tercium pada sistem limbik di dalam otak. Sistem limbik di dalam otak tidak hanya memproses penerima bau, namun juga mengatur emosi, sehingga dapat dipahami mengapa bau-bauan tertentu dapat mempengaruhi perasaan kita. Selain itu, sistem limbik juga berpengaruh terhadap produksi hormon.

Peneliti tidak menemukan teori yang membahas perbedaan dari aroma terapi lavender (lavandula angustifolia) dengan spray dan lilin terhadap tingkat insomnia, menurut asumsi peneliti bahwa penggunaan aroma terapi lavender spray dan lilin memiliki aroma dan kandungan yang sama sehingga mempunyai khasiat yang sama untuk merileksasikan tubuh dan merangsang rasa kantuk sehingga tidur lansia menjadi lebih nyenyak.

Penelitian Novianty (2015) tentang pengaruh terapi musik keroncong dan aromaterapi lavender (lavandula angustifolia) terhadap peningkatan kualitas tidur lansia di Panti Wredha Dharma Bhakti Kasih Surakarta. Hasil analisis statistik menggunakan uji Wilcoxon menunjukkan $p$ value sebesar 0,001 artinya ada pengaruh pemberian terapi musik keroncong dan aromaterapi lavender terhadap peningkatan kualitas tidur lansia

\section{KESIMPULAN}

1. Rata-rata skor tingkat insomnia lansia pada kelompok perlakuan sebelum diberikan aroma terapi lavender adalah 13,73 termasuk kategori tinggi. Ratarata skor tingkat insomnia lansia pada kelompok kontrol pre test adalah 13.45 termasuk kategori tinggi.

2 Rata-rata skor tingkat insomnia lansia pada kelompok perlakuan setelah diberikan aroma terapi lavender adalah 6,36 termasuk kategori rendah. Ratarata skor tingkat insomnia lansia pada kelompok kontrol post test adalah 6,91 termasuk kategori rendah.

3. Hasil hasil uji statistik Paired $t$ Test kelompok perlakuan didapatkan $\mathrm{p}$ value $=$ $0,000<\alpha 0,05$ menunjukkan ada pengaruh pemberian aroma terapi Lavender (Lavandula angustifolia) dengan spray terhadap tingkat insomnia pada kelompok perlakuan.. Hasil uji statistik Paired $t$ Test kelompok kontrol didapatkan nilai $\mathrm{p}$ value $=0,000>\alpha 0,05$ menunjukkan ada pengaruh pemberian aroma terapi Lavender (Lavandula angustifolia) dengan lilin terhadap tingkat insomnia pada kelompok kontrol. 
4. Hasil uji Independen T test didapatkan beda rata-rata skor tingkat insomnia kelompok perlakuan dan kelompok kontrol sebesar 0,545 dan nilai $\mathrm{p}$ value $=$ $0,443<0,05$ menunjukkan ada perbedaan tingkat insomnia pada lansia pada kelompok perlakuan yang diberikan aroma terapi lavender (lavandula angustifolia) dengan spray dan kelompok kontrol yang diberikan aroma terapi lavender (lavandula angustifolia) dengan lilin.

1. Bagi Puskesmas

\section{SARAN}

1) Melihat besarnya manfaat yang di timbulkan oleh pemberian aromterapi lavender ini terhadap tingkat insomnia lansia maka pemberian aromaterapi lavender dapat dijadikan sebagai salah satu intervensi yang dapat diberikan oleh pihak puskesmas untuk menurunkan tingkat insomnia pada lansia

2) Hasil penelitian ini diharapkan dapat digunakan untuk membuat kebijakan tentang pencegahan insomnia pada lansia dengan cara melakukan edukasi kepada keluarga tentang insomnia serta melakukan kunjungan rumah (home care) ke rumah lansia yang mengalami insomnia

2. Keluarga

Keluarga dapat menerapkan penggunaan aroma terapi lavender seperti yang sudah diajarkan ketika lansia kembali mengalami gangguan tidur serta menghindari lansia dari stresor yang dapat menimbulkan gangguan tidur seperti lingkungan yang bising.

3. Bagi peneliti selanjutnya

1) Dapat dijadikan sebagai inspirasi maupun masukan untuk penelitian lain agar dapat mengembangkan penelitian terhadap lanjut usia dan terapi-terapi yang sesuai dengan bidang keperawatan baik terapi nonfarmakologi atau terapi komplementer.

2) Diharapkan dapat menggunakan metode penelitian lain dengan menghubungkan faktor - faktor lain yang mempengaruhi terjadinya insomnia, menambah populasi dan sampel agar hasilnya lebih valid dan representative

\section{DAFTAR PUSTAKA}

Arikunto. 2012. Manajemen Penelitian. Jakarta : PT Rineka Cipta Aspiani. 2014. Buku Ajar Keperawatan Gerontik. Jakarta: CV. Trans Info Media. Azizah. 2011. Keperawatan Lanjut Usia. Edisi 1.Yogyakarta : Graha Ilmu Aziz. 2016. Pengaruh Aromaterapi Sereh Terhadap Penurunan Insomnia Pada Lansia Di Panti Wredha Daerah Surakarta. Available: http://www.journal.ui.ac.id/home/ (akses 2 Maret 2017)

Badan Pusat Statistik RI. 2013. Penduduk Indonesia Menurut Umur dan Jenis Kelamin dalam Angka Provinsi Bali. Online available : http://www.bps.com/. Diakses tanggal 25 Maret 2016.

Bararah. 2015. Jenis Aromaterapi dan Manfaatnya. Online available : http:// www.indospiritual.com. Diakses tanggal 25 Maret 2017.

Bassil. 2011. How Anxiety Presents Differently In Older Adults. Current Psychiatry Vol.10, No.3, 65-71.

Buckle, Jane . 2011. The Role of Aromatherapyin Nursing Care. Nursing Clinics of North America 
Catterhine. 2010. Lavender Oil. Online available : www//http://Wikkipedia, free encyclopedia.mht. Diakses tanggal 25 Maret 2016

Dahlan. 2013. Statistik Untuk Kedokteran dan Kesehatan Edisi 5. Jakarta, Salemba Medika

DepKes RI. 2013. Riset Kesehatan Dasar. Jakarta : Badan Penelitian dan Pengembangan Kesehatan Kementerian Kesehatan RI

Dewi \& Prima. 2011. Aromaterapi Lavender Sebagai Media Relaksasi. Semarang: Bagian Farmasi Fakultas Kedokteran Universitas Udayana.

Dinas Kesehatan Provinsi Bali .2015. Profil Kesehatan Provinsi Bali. Denpasar : Dinas Kesehatan

Dinas Kesehatan Kabupaten Gianyar.2015. Profil Kesehatan Kabupaten Gianyar. Gianyar : Dinas Kesehatan

Flora Serial. 2010. Terapi Aromatik Mendongkrak Gairah Bercinta. Jakarta : Majalah Flora PT Samindra Utama

Gellis. 2014. Chapter 2: Anxiety Disorders In Older Adults. Council On Social Work Education, 1-19.

Gitahafas. 2011. Kesehatan Lansia. (Online) available : http://www. health.detik.com. Diunduh tanggal 12 Maret 2017.

Hawari, D. 2009. Manajemen Cemas dan Depresi. Jakarta: Balai Penerbit Fakultas Kedokteran Universitas Indonesia

Hadibroto \& Alam. 2012. Seluk Beluk Pengobatan Alternatif Dan Komplementer. Jakarta: Pt Bhuana Ilmu Populer.

Heningsih. 2014. Gambaran Tingkat Ansietas Pada Lansia Di Panti Wredha Darma Bakti Kasih Surakarta. Online available : http:/www.e-jurnal.com/. Diakses tanggal 18 Maret 2017.

Hermayudi. 2012. Gambaran Kejadian Insomnia Pada Lansia di Panti Wredha Dharma Bhakti Surakarta. Available: http://www.journal.ui.ac.id/home/ (akses 2 Maret 2017)

Hidayat. 2014. Metode Penelitian dan Teknik Analisis Data. Jakarta : Penerbit Salemba Medika

Hutasoit. 2012. Aroma Terapi. Jakarta : Pustaka Populer Obor

Ilmiasih. 2012. Hubungan Antara Perilaku Olahraga, Stress Dan Pola Makan Dengan Tingkat Hipertensi Pada Lanjut Usia Di Posyandu Lansia Kelurahan Gebang Putih Kecamatan Sukolilo Kota Surabaya. Available: http://www.journal.ui.ac.id/home/ (akses 2 Maret 2017)

Jaelani. 2012. Aroma Terapi. Jakarta: Pustaka Populer Obor

Keliat. 2010. Keperawatan Kesehatan Jiwa Komunitas. Jakarta: EGC.

Kemenkes, RI, 2013. Buletin Gambaran Kesehatan Lanjut Usia di Indonesia. Jakarta. from: www.depkes.go.id/downloads/Buletinla nsiapdf ( accesed 26 Maret 2016)

Kusmiati, M.S. 2015. Pengaruh Pemberian Aromaterapi Kenanga (cananga odorata) terhadap penurunan tingkat kecemasan pada lansia (usia 60-74 tahun) di Panti Werdha Mental Kasih Desa Turi Kecamatan Turi Kabupaten Lamongan. Skripsi Program Studi Ilmu Keperawatan STIKES Muhammadiyah Lamongan

Kristanti, E.E. 2010. Pengaruh Aromaterapi Lavender Terhadap Penurunan Depresi pada Lansia di Panti Wredha St. Yoseph Kediri. Online available : http://www.e-jurnal.com/. $\quad$ Diakses tanggal 18 Maret 2017. 
Laraswati. 2014. Faktor-Faktor Yang Menyebabkan Gangguan Tidur (Insomnia) Pada Lansia Di Unit Pelayanan Teknis Kesehatan Masyarakat Ubud I Tahun 2014. Politeknik Kesehatan Denpasar Jurusan Keperawatan Program DIII Keperawatan

Lumbantobing. 2010. Kecerdasan Pada Usia Lanjut Dan Demensia. Edisi 4. Jakarta: Balai penerbit FKUI.

Maryam. 2010. Mengenal usia lanjut dan penangannya. Jakarta: Salemba Medika.

Mirayanti. 2015. Hubungan Antara Fungsi Keluarga Dengan Kualitas Hidup Lansia Di Banjar Penopengan Desa Sanur Kauh Kecamatan Denpasar Selatan Tahun 2015. Skripsi Sekolah Tinggi Ilmu Kesehatan Bali

Mubarak, W, I, dkk. 2009. Ilmu Keperawatan Komunitas Konsep dan Aplikasi. Jakarta: Salemba Medika.

Muchtaridi. 2013. Tinjauan Aktivitas Farmakologi Aromaterapi. Available: https://tamanlavender.wordpress.com. Diakses 2 Maret 2017)

MacKinnon, Karen J. 2012. Aromatherapy: Art or Science? Highlights of Aromatherapy in Medicine Today: Retrivied 16 Maret 2016 http://www.inetce.com/articles/pdf/221- 999-04-095-H01.pdf.

McLain DE. 2009. Arpmatherapy Practice in Nursing : Literature Rievew. Journal of Advanced Nursing, Volume: 48, Issue : (1)93-103 : Retrivied 11 Maret 2017

Novianty. 2015. Pengaruh Terapi Musik Keroncong Dan Aromaterapi Lavender (Lavandula Angustifolia) Terhadap Peningkatan Kualitas Tidur Lansia di Panti Wredha Dharma Bhakti Kasih Surakarta. Online available : http://www.e-jurnal.com/. Diakses tanggal 8 Mei 2017.

Nugroho. 2014. Keperawatan Gerontik \& Geriatrik, ed 3. Jakarta : EGC

Nuraini. 2014. Aneka Manfaat Bunga Untuk Kesehatan. Yogyakarta: Gaya Media

Nursalam. 2013. Konsep dan Penerapan Metodelogi Penelitian Ilmu Keperawatan,Pedoman Skripsi, Tesis, dan Instrumen Penelitian Keperawatan, Edisi 2, Jakarta : Salemba Medika

Potter and Perry. 2010. Buku Ajar Fundamental Keperawatan : Konsep, Proses dan Praktik. Edisi 4. Jakarta : EGC

Pudjiastuti. 2013. Penyakit penyakit mematikan. Yogjakarta : Nuha Medika

Rahmawati. 2015. Efektifitas Mandi Air Hangat Dan Aroma Terapi Lavender Terhadap Insomnia Pada Lansia. Jurnal: Tesis Universitas Diponegoro.

Sharma. 2010. Aroma Terapi. Tangerang : Karisma

Suarjani. 2015. Hubungan Self Care Management dengan Kualitas Hidup Lansia Hipertensi di Desa Tegallalang Wilayah Kerja Puskesmas Tegallalang I Gianyar Tahun 2015. Skripsi StiKes Wira Medika PPNI Bali

Suliswati. 2010. Konsep Dasar Keperawatan Jiwa.Jakarta : EGC

Sugiyono. 2012. Metode Penelitian Pendidikan. Bandung : CV Alfabeta

Supiani. 2014. Pengaruh Pemberian Aroma Terapi Lavender (Lavandula Angustifolia) Terhadap Penurunan Hipertensi Pada Lansia di Desa Cemagi, Kecamatan Mengwi, Kabupaten Badung. Skripsi Prodi S1 Keperawatan, STIKES Bina Usada Bali

Suryati. G.A. 2015. Efektifitas Pemberian Aromaterapi Lavender Terhadap Penurunan Tingkat Kecemasan Pada Lanjut Usia di panti graha kasih bapa Kabupaten Kubu Raya. Online available : http://www.e-jurnal.com/. Diakses tanggal 18 Maret 2017. 
Wijayanti. 2014. Aroma Terapi lavender (Lavandula angustifolia). Tangerang : Karisma

Word Health Organitation. 2015. WHO Global Report on Falls Prevention in Older Age. Perancis: WHO. 